\title{
Spatial distribution of ciliates, copepod nauplii and eggs, Engraulis japonicus post-larvae and microzooplankton herbivorous activity in the Yellow Sea, China
}

\author{
Wuchang Zhang ${ }^{1, *}$, Kuidong $\mathrm{Xu}^{2}$, Ruijing Wan ${ }^{3}$, Guangtao Zhang ${ }^{1}$, \\ Tianxiang Meng ${ }^{3}$, Tian Xiao ${ }^{1}$, Rong Wang ${ }^{1}$, Song Sun ${ }^{1}$, Joong Ki Choi ${ }^{2}$ \\ ${ }^{1}$ Department of Marine Ecology, Institute of Oceanography, Chinese Academy of Sciences, 266071 Qingdao, PR China \\ ${ }^{2}$ Regional Research Center for Coastal Environments of Yellow Sea, Inha University, Inchon 402-751, Korea \\ ${ }^{3}$ Yellow Sea Fisheries Research Institute, Chinese Academy of Fishery Sciences, 106 Nanjing Road, 266071 Qingdao, PR China
}

\begin{abstract}
The abundance of anchovy Engraulis japonicus larvae, $>20 \mu \mathrm{m}$ ciliates, copepod eggs and nauplii, and microzooplankton herbivorous activity were studied in the Yellow Sea in June 2000. Anchovy juveniles and larvae were found in only 6 of the 19 stations sampled. The ciliate communities were dominated by 2 species: Laboea strobila and Strombidium compressum. In the surface waters, the abundance of $L$. strobila ranged between 0 and 560 ind. $1^{-1}$. S. compressum only appeared at Stns 15 to 18 (20 to 3300 ind. $\mathrm{l}^{-1}$ ). L. strobila was found mainly in the top $20 \mathrm{~m}$. The abundance of L. strobila was less than 50 ind. $\mathrm{l}^{-1}$ in waters deeper than $25 \mathrm{~m}$. S. compressum showed subsurface abundance peaks at the salinity abnormality. Tintinnids occurred occasionally with abundance lower than 100 ind. $\mathrm{l}^{-1}$. The total ciliate abundance fell in the range of 40 to $3420 \mathrm{ind} . \mathrm{l}^{-1}$. The ciliate biomass in the surface water and the water column ranged between 0.15 and $6.76 \mu \mathrm{g} \mathrm{Cl}^{-1}$ and 0.4 and $134.4 \mathrm{mg} \mathrm{C} \mathrm{m}{ }^{-2}$, respectively. In the surface waters, the abundance of copepod eggs and nauplii ranged from 0.3 to 3.1 and 1.1 to 15.6 ind. $\mathrm{l}^{-1}$, respectively. The average abundance of copepod eggs and nauplii in 4 depth $(0,5,10$ and $20 \mathrm{~m})$ fell in the range of 0.2 to 2.8 and 1.0 to $29.4 \mathrm{ind}^{-1} \mathrm{l}^{-1}$, respectively. As a food item of the E. japonicus post-larvae, the abundance of copepod nauplii and eggs appeared to be low. The abundance peaks of ciliate and E. japonicus post-larvae coincided. Although not found in the gut of E. japonicus post-larvae, aloricate ciliates might be ingested by first-feeding anchovy larvae, preventing initial starvation and prolonging the time to irreversible starvation. On the basis of dilution experiments with positive microzooplankton grazing rates, microzooplankton grazed at rates of 0 to $0.61 \mathrm{~d}^{-1}$. Grazing pressure of microzooplankton on chlorophyll a standing stock $\left(P_{\mathrm{i}}\right)$ and potential chlorophyll a primary production $\left(P_{\mathrm{p}}\right)$ were 17 to $46 \%$ and 35 to $109 \% \mathrm{~d}^{-1}$, respectively.
\end{abstract}

KEY WORDS: Ciliate $\cdot$ Engraulis japonicus $\cdot$ Microzooplankton $\cdot$ Dilution incubation

\section{INTRODUCTION}

Planktonic ciliates are a morphologically diversified group and are usually divided into loricate (tintinnid) and aloricate (naked) forms. In most marine ecosystems, they dominate the microzooplankton (Beers et al. 1980,

*E-mail: w.c.zhang@yeah.net
Uye et al. 1996), which is the trophic link between the microbial food web and the metazoans (Stoecker \& Capuzzo 1990, Gifford 1991). Ciliates are also food items of fish larvae. Tintinnids have been found in the gut of field-collected fish larvae (Jenkins 1987, Govoni \& Chester 1990). There is no evidence that fish larvae feed upon naked ciliates in the field because no hard parts of naked ciliates can be identified in the gut of field- 
collected fish larvae. However, naked ciliates were ingested in experimentally reared fish larvae as shown by different techniques (Ohman et al. 1991, Lessard et al. 1996, Nagano et al. 2000). Ohman et al. (1991) detected naked ciliate components in the gut of larval anchovy by immunochemical methods. Using ciliates labeled with 2,4-diamadino-6-phenylindole (DAPI) and fluorescent microspheres, respectively, Lessard et al. (1996) and Nagano et al. (2000) found a trace of ciliates in the guts of fish larvae. In the field, naked ciliates may be more important food for fish larvae than tintinnids because the abundance of naked ciliates is much greater than that of tintinnids (Pierce \& Turner 1992).

China-GLOBEC II (Global Ocean Ecosystem Dynamics) has chosen the Eastern China and Yellow Seas to be the study area. Among the 12 projects of ChinaGLOBEC II were the early recruitment mechanisms of key species (e.g. Engraulis japonicus, an anchovy) and process studies on microbial and microplankton production (Tang 2000). From 1997 to 1999, the catch of $E$. japonicus was more than 1 million tons $\mathrm{yr}^{-1}$, which constituted 20 to $25 \%$ of the annual fishery catch in the whole country. The anchovy spawn in the Yellow Sea in May and June (Zhu \& Iversen 1990). It has long been proposed that the strength of a year-class of fish stock is most probably determined by the mortality at the earliest larval feeding stage (the so-called 'critical period' stated by May 1974), and the mortality is dependent upon the food density when they first begin to feed (Hjort 1914). Copepod nauplii were reported to be numerically the most important food items of E. japonicus larvae by examining the larval gut (Hirakawa et al. 1997). In order to investigate the early recruitment mechanisms of this species, a cruise was carried out during June 13 to 28,2000 . The abundance of copepod nauplii and ciliates, which can be potential food items of anchovy larvae, were studied in this cruise. Microzoopankton herbivorous activities were also evaluated using the dilution incubation technique.

\section{MATERIALS AND METHODS}

Stations. Measurements were made on board RV 'Beidou' during June 13 to 28, 2000. The study stations are shown in Fig. 1. Nineteen grid stations (Stns 1 to 19) with depths between 22 (Stn 4) and $79 \mathrm{~m}$ (Stn 8) were investigated from June 13 to 18. At each of the grid stations, an SBE19 Seacat Profiler (Model SBE1903) was cast at first and the profiles of temperature and salinity were displayed using the Seasoft ${ }^{\circledR}$ (version 4.233) software (Sea-Bird Electronics) immediately onboard the ship. Water samples for the chemical and biological studies were collected with 2.51 Niskin bottles on a Rossette conductivity, temperature and depth
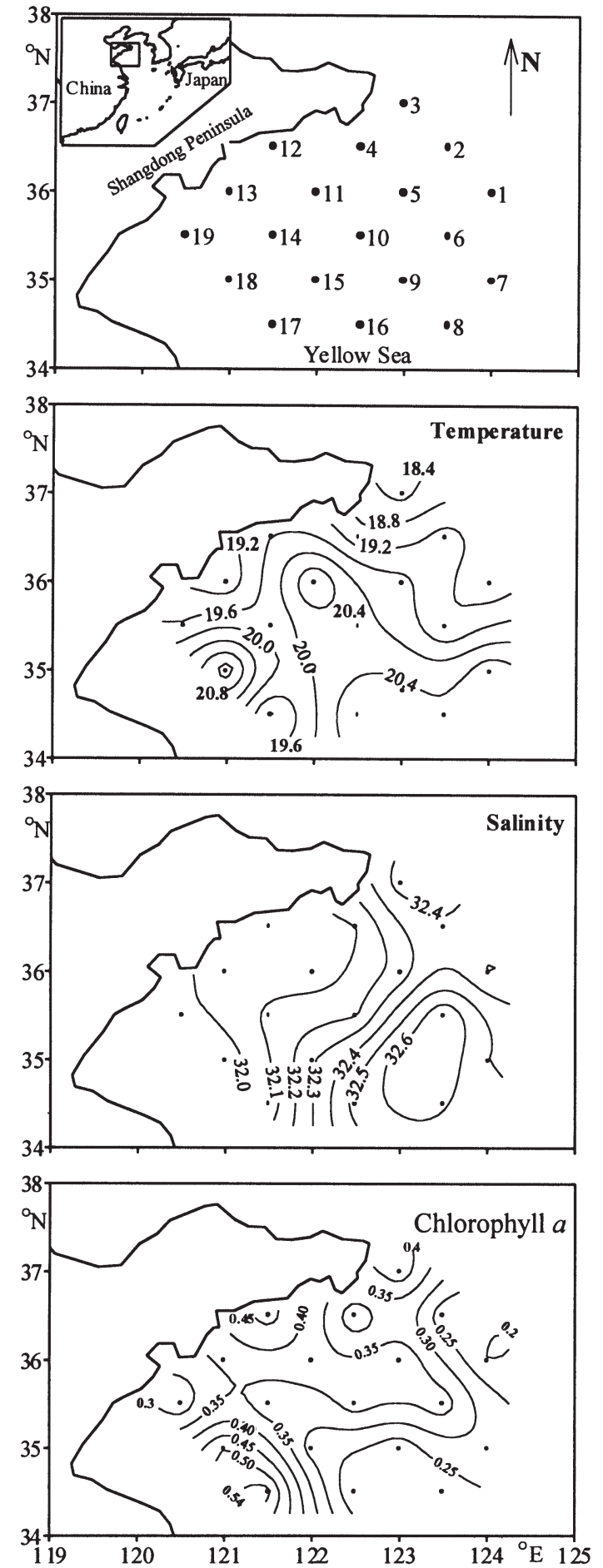

Fig. 1. Map of the study area and the distributions of surface temperature $\left({ }^{\circ} \mathrm{C}\right)$, salinity and chlorophyll a concentration $\left(\mu \mathrm{g} \mathrm{l}^{-1}\right)$

profiler (CTD). Sample depths (generally 4 to 6 depths) were chosen depending on the location of the thermocline. Nutrients were analyzed by colorimetry method (Zhang et al. 1997). 
One liter of surface water was sampled to measure the chlorophyll a concentration. Chlorophyll a concentration was determined as follows. Water samples were filtered through GF/F glass fiber filters. The filters were extracted with $90 \%$ acetone at $-20^{\circ} \mathrm{C}$ in darkness for $24 \mathrm{~h}$. The concentrations were determined using a Turner Designs (Model II) fluorometer that was calibrated with pure chlorophyll a from Sigma (Strickland \& Parsons 1972).

Anchovy eggs and larvae. At each station, abundances of anchovy larvae and eggs were investigated by horizontally towing a net $(0.8 \mathrm{~m}$ mouth diameter with $500 \mu \mathrm{m}$ mesh, $2.7 \mathrm{~m}$ in length) on the sea surface at a speed of 3.2 knots. The unit of anchovy larvae abundance, ind. net ${ }^{-1}$, means the catch in a $10 \mathrm{~min}$ towing (towing distance was ca $988 \mathrm{~m}$ ). The total body lengths were measured, and gut contents of anchovy larvae and juveniles were examined using a stereomicroscope.

Ciliates. A 11 sample of water from each depth was poured into a 11 plastic bottle and fixed in $1 \%$ acid Lugol's iodine solution (Longhurst et al. 1990, Harris et al. 2000). The bottles were stored cool and in darkness until analyzed in the laboratory within $2 \mathrm{mo}$. In the laboratory, the fixed water samples were settled for at least $24 \mathrm{~h}$ in the plastic bottles. The upper water was siphoned out and $100 \mathrm{ml}$ was left. Then $25 \mathrm{ml}$ (50 or $100 \mathrm{ml}$ if necessary) of the samples was settled in sedimentation chambers and counted using a Zeiss microscope at $150 \times$ magnification. In each sample, ciliates (including aloricate ciliates and tintinnids) with a minimum preserved dimension of $>20 \mu \mathrm{m}$ were counted.

For taxonomic studies, Lugol's solution-fixed samples were replaced by Bouin's fluid for protargol staining (Lynn 1992). The protargol impregnation technique (Wilbert 1975) was partially used to reveal the infraciliature of ciliates, regarded as the key feature for identification. The classification of ciliates was based on common literature (Kofoid \& Campbell 1929, Maeda \& Carey 1985, Small \& Lynn 1985, Lynn et al. 1991, 1988, Montagnes \& Lynn 1991, Carey 1992). The dimensions of the ciliates were measured and the cell volume of each species was estimated using appropriate geometric shapes (cone, ball, cylinder, cuneiform and their combinations). The carbon:volume ratio used to calculate biomass was 0.19 pg $\mathrm{C} \mu \mathrm{m}^{-3}$ (Putt \& Stoecker 1989). The plasma of tintinnids was assumed to occupy $30 \%$ of the lorica volume (Gilron \& Lynn 1989). Water column biomass was calculated as the integral of the biomass from bottom to surface.

Copepod eggs and nauplii. A large-volume (60 1) water sampler was used to collect water from different depths $(0,5,10,20 \mathrm{~m}$ and so on) at every grid station. The water samples were poured into a net $(38 \mu \mathrm{m}$ mesh size). Copepod eggs and nauplii in the cod end were preserved with a $5 \%$ buffered formalin-seawater solution. Abundances of eggs and nauplii were counted under dissecting microscope later in the laboratory.

Dilution incubations. After the grid investigation, anchovy eggs, of which $99 \%$ were dead, were found only at Stn 10 . The peak of anchovy larvae abundance was found at Stn 17. These 2 positions were taken as anchor stations. After the investigation at anchor Stn 10, the larvae peak, which appeared at Stn 17 during the grid investigation, moved to the position of Stn 18. As a result, Stns 10 and 18 were the anchor stations.

A total of 6 dilution incubation experiments were carried out (Table 1 ) at the 2 anchor stations. The experimental protocols by Landry \& Hassett (1982) and Burkill et al. (1990) were followed. The experimental items including 251 polycarbonate carboy, 1.51

Table 1. Results of the dilution incubation experiments in June 2000. Chl a: chlorophyll $a_{i} g$ : microzooplankton grazing rate; $k$ : potential phytoplankton growth rate; $P_{\mathrm{i}}$ : microzooplankton grazing pressure on chl a standing stock; $P_{\mathrm{p}}$ : primary production. The unit of nutrient concentration is $\mu_{\mathrm{mol}} \mathrm{l}^{-1}$

\begin{tabular}{|c|c|c|c|c|c|c|c|c|c|c|c|c|}
\hline $\begin{array}{l}\text { Station/ } \\
\text { depth (m) }\end{array}$ & $\begin{array}{c}\text { Time } \\
\text { (hour/date) }\end{array}$ & $\mathrm{NH}_{4}^{+}$ & $\mathrm{NO}_{2}^{-}$ & $\mathrm{NO}_{3}{ }^{-}$ & $\mathrm{PO}_{4}{ }^{3-}$ & $\mathrm{SiO}_{3}{ }^{3-}$ & $\begin{array}{c}\text { Chl a } \\
\left(\mu \mathrm{g} \mathrm{l}^{-1}\right)\end{array}$ & $\begin{array}{c}k \\
\left(\mathrm{~d}^{-1}\right)\end{array}$ & $\begin{array}{c}g \\
\left(\mathrm{~d}^{-1}\right)\end{array}$ & $r^{2}$ & $\begin{array}{c}P_{\mathrm{i}} \\
(\%)\end{array}$ & $\begin{array}{c}P_{\mathrm{p}} \\
(\%)\end{array}$ \\
\hline $\begin{array}{l}\text { Stn 10/ } \\
10\end{array}$ & $\begin{array}{c}12: 00 / 19 \text { to } \\
12: 00 / 20\end{array}$ & 1 & 0.05 & 0.38 & 0.04 & 0.80 & 0.22 & 0.52 to 0.7 & 0 & - & - & - \\
\hline $\begin{array}{l}\text { Stn10/ } \\
10\end{array}$ & $\begin{array}{c}09: 00 / 21 \text { to } \\
09: 00 / 22\end{array}$ & 0.54 & 0.01 & 0.53 & 0.01 & 0.38 & 0.25 & $\begin{array}{c}0.74 \\
(0.080)\end{array}$ & $\begin{array}{c}0.41 \\
(0.116)\end{array}$ & 0.67 & 34 & 64 \\
\hline $\begin{array}{l}\operatorname{Stn} 10 / \\
0\end{array}$ & $\begin{array}{c}10: 30 / 21 \text { to } \\
10: 30 / 22\end{array}$ & 0.71 & 0.01 & 0.84 & 0.00 & 0.47 & 0.18 & $\begin{array}{c}0.14 \text { to } \\
0.52\end{array}$ & 0 & - & - & - \\
\hline $\begin{array}{l}\text { Stn18/ } \\
0\end{array}$ & $\begin{array}{c}08: 00 / 23 \text { to } \\
08: 00 / 24\end{array}$ & 0.96 & 0.06 & 0.83 & 0.05 & 1.09 & 0.78 & $\begin{array}{c}0.64 \\
(0.042)\end{array}$ & $\begin{array}{c}0.61 \\
(0.029)\end{array}$ & 0.97 & 46 & 97 \\
\hline $\begin{array}{l}\text { Stn18/ } \\
10\end{array}$ & $\begin{array}{c}11: 00 / 23 \text { to } \\
11: 00 / 24\end{array}$ & 0.74 & 0.08 & 0.24 & 0.06 & 4.33 & 0.92 & $\begin{array}{c}0.20 \\
(0.056)\end{array}$ & $\begin{array}{c}0.22 \\
(0.082)\end{array}$ & 0.56 & 20 & 109 \\
\hline $\begin{array}{l}\text { Stn18/ } \\
0\end{array}$ & $\begin{array}{c}09: 00 / 25 \text { to } \\
09: 00 / 26\end{array}$ & 0.50 & 0.03 & 0.57 & 0.08 & 0.28 & 0.55 & $\begin{array}{c}0.69 \\
(0.045)\end{array}$ & $\begin{array}{c}0.19 \\
(0.066)\end{array}$ & 0.58 & 17 & 35 \\
\hline
\end{tabular}


polycarbonate bottles, glass filter bottles, etc. were soaked with $10 \% \mathrm{HCl}$ and rinsed with filtered seawater (FSW) before use. At each of the above stations, the 0 and $10 \mathrm{~m}$ waters were chosen as experimental depths. To begin incubation, 241 seawater from the goal depth was collected using Niskin bottles and transferred to a polycarbonate carboy. Part of this water was filtered through GF/F filters. The FSW was assumed to be free of predator and prey. The FSW was added to make concentrations of $100,75,50$ and $25 \%$
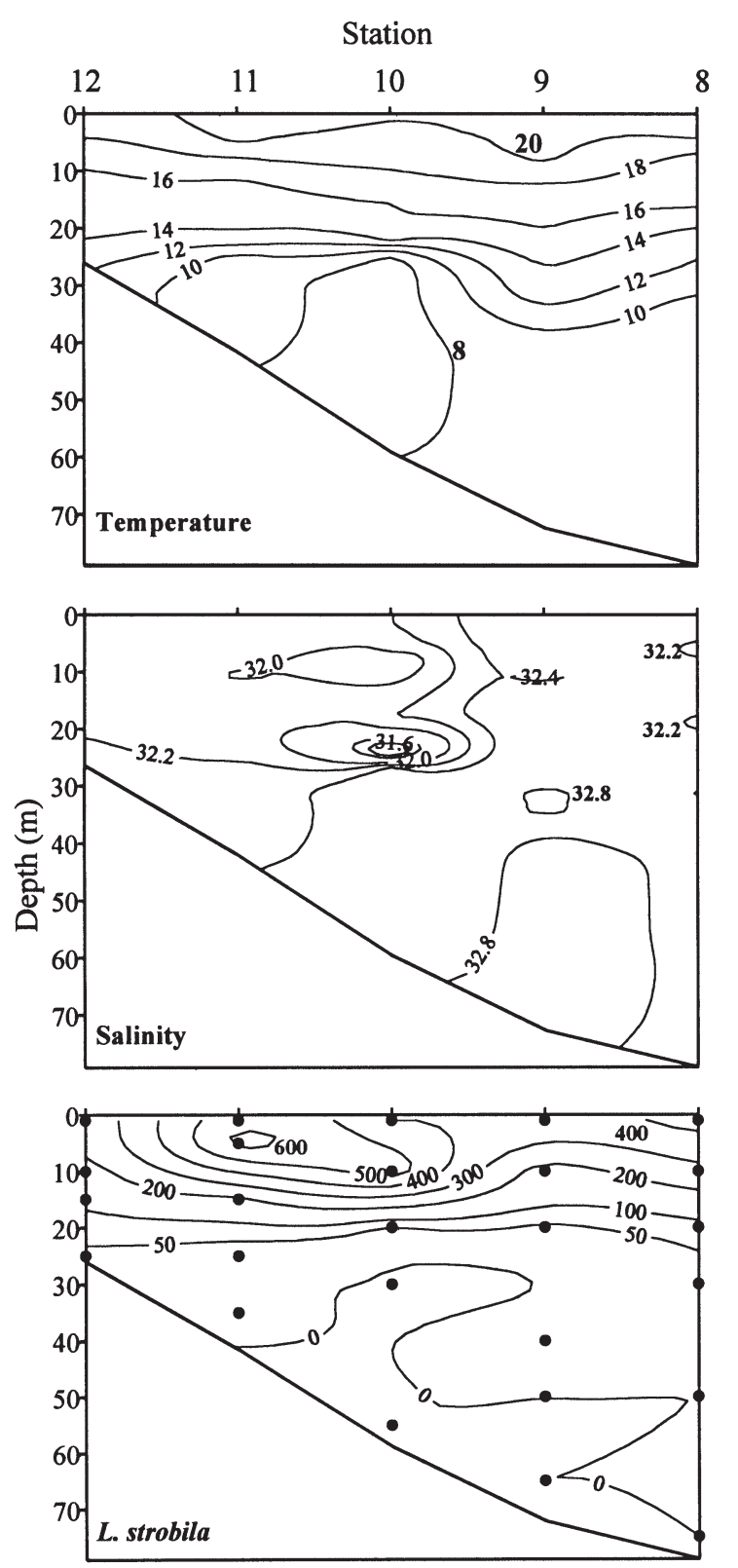

Fig. 2. Vertical distributions of temperature $\left({ }^{\circ} \mathrm{C}\right)$, salinity and Laboea strobila abundance (ind. $\mathrm{l}^{-1}$ ) along the transect through Stns 8 to 12 (dilution factor) of ambient seawater in polycarbonate bottles. A mesh $(38 \mu \mathrm{m})$ was used to eliminate the macrozooplankton. From each concentration, $500 \mathrm{ml}$ water was sampled for the determination of initial chlorophyll a concentration. The rest of the water was poured into two $1.5 \mathrm{l}$ polycarbonate bottles. Caution was taken to avoid air bubbles in the bottles. We did not add nutrients to the dilution bottles.

The bottles were incubated in 2 plastic boxes (semitransparent with the openings upward) at $10 \mathrm{~m}$ depth suspended from the ship or in a temperature-control container (not transparent) under natural light on board the ship. In the latter case, the surface water was pumped and flowed through the container to maintain the in situ temperature. Further samples for chlorophyll a concentration were taken after $24 \mathrm{~h}$ incubation. Chlorophyll a concentrations were determined as described above.

According to Landry \& Hassett (1982), microzooplankton grazing rate $\left(g, \mathrm{~d}^{-1}\right)$ and the potential phytoplankton growth rate $\left(k, \mathrm{~d}^{-1}\right)$ can be expressed as follows:

$$
1 / t \ln \left(P_{t} / P_{0}\right)=k-c \times g
$$

where $P_{t}$ is the chlorophyll a concentration at time $t_{i} P_{0}$ is the initial chlorophyll a concentration; and $C$ is the dilution factor. Values of $k$ and $g$ were determined from linear regression of the apparent chlorophyll $a$ growth rates against the dilution factors. Microzooplankton grazing pressure on chlorophyll a standing stock $\left(P_{\mathrm{i}}\right)$ and primary production $\left(P_{\mathrm{p}}\right)$ were calculated according to Verity et al. (1993):

$$
\begin{gathered}
P_{\mathrm{i}}=1-\mathrm{e}^{-g t} \times 100 \% \\
P_{\mathrm{p}}=\left[\mathrm{e}^{k t}-\mathrm{e}^{(k-g) t}\right] /\left(\mathrm{e}^{k t}-1\right) \times 100 \%
\end{gathered}
$$

\section{RESULTS}

\section{Hydrographic conditions and chlorophyll a}

The surface temperature was between 18.3 and $21.5^{\circ} \mathrm{C}$. Water temperature in the northern part of the study area was lower than that in the south. But surface temperature at Stn 17 was comparatively low in the southwestern part of the study area (Fig. 1). The vertical profile of temperature showed strong stratification. All of the stations showed obvious thermoclines at different depths. For example, temperature drops from the surface to about $30 \mathrm{~m}$ along the transect through Stns 8 to 12 . Waters below $30 \mathrm{~m}$ were lower than $9^{\circ} \mathrm{C}$ (Fig. 2). In the surface waters, salinity (31.95 to $32.70 \%$ ) was lower in the near shore area (Fig. 1). Parallel to the surface salinity contour in Fig. 1, there 


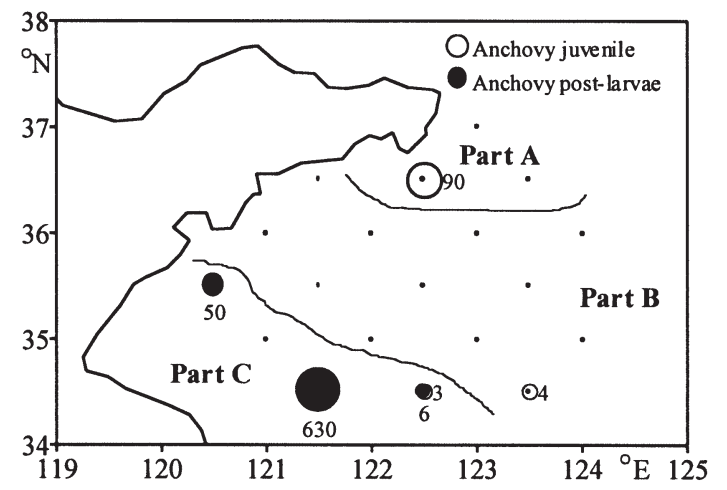

Fig. 3. Chart showing the division of the study area. The numbers in the figure indicate the abundance (ind. net ${ }^{-1}$ ) of the anchovy juveniles and post-larvae. Numbers to the right of the circles: abundance of juveniles. Numbers below the circle: abundance of post-larvae

was a zone with low salinity at $26 \mathrm{~m}$ depth (Fig. 2). Chlorophyll a concentrations in the surface waters ranged between 0.20 and $0.56 \mu \mathrm{g} \mathrm{l}^{-1}$ (Fig. 1). The maximum concentration was at Stn 17.

\section{Anchovy eggs and larvae, gut content of larvae}

Anchovy eggs, of which $99 \%$ were dead, were found only at Stn 10. The distribution of anchovy larvae is shown in Fig. 3. At Stn 4, 90 ind. net ${ }^{-1}$ anchovy juveniles (20 to $25 \mathrm{~mm}$ in total body length) were found. There were only 4 and 3 ind. net ${ }^{-1}$ of juveniles at Stns 8 and 16, respectively. There were 630 post-larvae (5 to $10 \mathrm{~mm}$ in total body length, 2.5 to $8.9 \mathrm{~mm}$ in notochord length) and 12 pre-larvae net ${ }^{-1}$ at Stn 17 . Fifty postlarvae net ${ }^{-1}$ were found at Stn 19 . The abundance of anchovy larvae at other stations was even lower.

Food incidence (percentage of larvae containing at least one food particle for a particular sample) was $16.2 \%$. Gut contents of the post-larvae were dinoflagellates, copepods of different development stages (eggs, nauplii), etc. Numerically, copepod eggs and nauplii accounted for 42 and $30.4 \%$, respectively, of the food particles found in the guts of anchovy larvae.

\section{Ciliate composition and distribution}

A total of 17 species were identified, as listed in Table 2. There were 2 dominant ciliates: Laboea strobila Lohmann, 1908 and Strombidium compressum Kahl, 1932. In the surface waters, the abundance of $L$. strobila ranged between 0 (Stns 3, 4 and 17) and 560 ind. $\mathrm{l}^{-1}$ (Stn 11). Stns 7, 8, 10 and 11 had abundances more than 400 ind. $\mathrm{l}^{-1}$ (Fig. 4). S. compressum
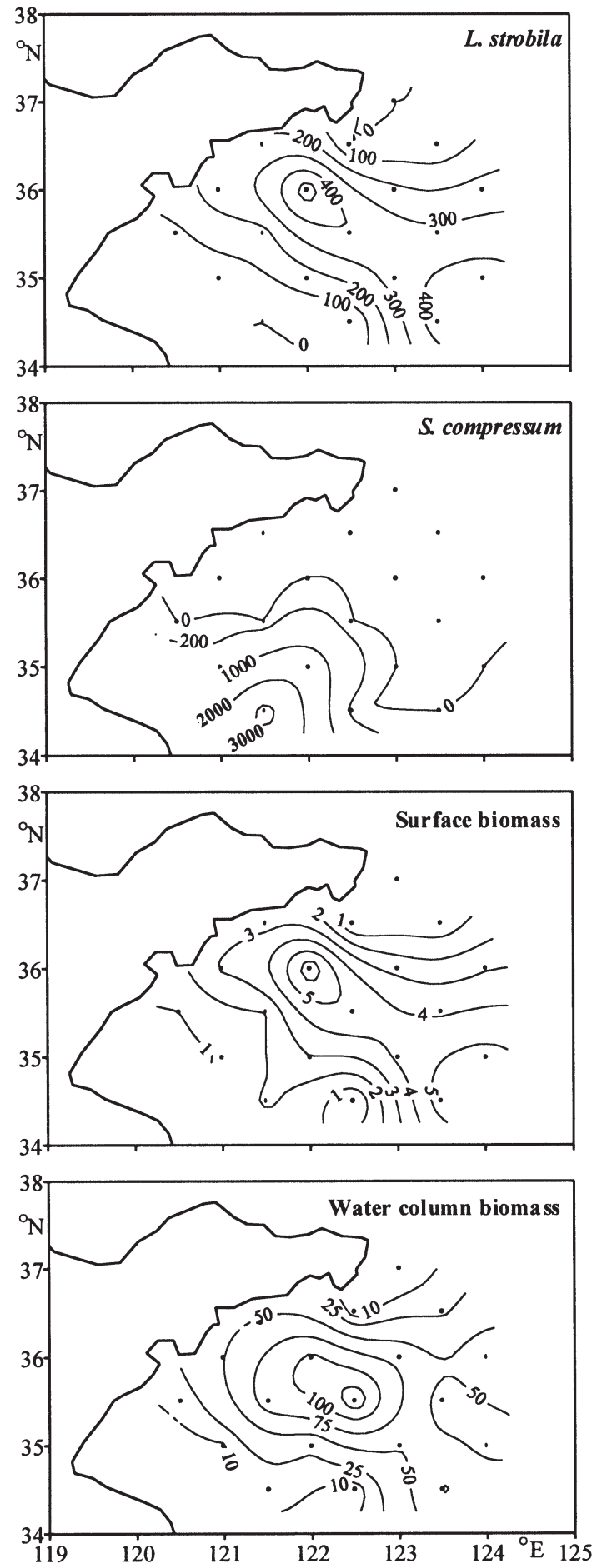

Fig. 4. Spatial distributions of the abundance (ind. $\mathrm{l}^{-1}$ ) of Laboea strobila, abundance (ind. $\mathrm{l}^{-1}$ ) of Strombidium compressum, ciliate surface biomass $\left(\mu \mathrm{g} \mathrm{Cl}^{-1}\right)$ and ciliate water column biomass $\left(\mathrm{mg} \mathrm{C} \mathrm{m}^{-2}\right)$

only appeared in Stns 15 to 18 (1632, 20, 3300 and 480 ind. $\mathrm{l}^{-1}$, respectively).

Vertically, Laboea strobila occurred mainly above $20 \mathrm{~m}$. The maximum abundance was 640 ind. $\mathrm{l}^{-1}$ at the 
Table 2. List of ciliate taxa found in the Yellow Sea

\begin{tabular}{|lc|}
\hline Taxon & $\begin{array}{c}\text { Size (length } \times \text { maximum width) } \\
(\mu \mathrm{m})\end{array}$ \\
\hline Oligotrichida & \\
Oligotrichina & \\
Laboea strobila & $100-120 \times 45-50$ \\
Strombidium compressum & $25-30 \times 20-25$ \\
Strombidium reticulatum & $30-50 \times 20-35$ \\
Strombidium sp. & $18-20 \times 15-20$ \\
Strombidinopsis sphaira & $30 \times 25$ \\
Tintinnina & \\
Tintinnopsis beroidea & $50-60 \times 25-30$ \\
Codonelopsis lusitanica & $85 \times 40$ \\
Stenosemella pacifica & $40 \times 35$ \\
Stenosemella steini & $80-90 \times 70-80$ \\
Parafavella ventricola & $310-420 \times 65-80$ \\
Gymnostomatea & \\
Mesodinium pupula & $25-30 \times 18-20$ \\
Mesodinium pulex & $18-25 \times 15-18$ \\
Mesodinium rubrum & $25-30 \times 20-25$ \\
Didinium gargantua & $85-90 \times 55-60$ \\
Cyclotrichium sphaericum & $75-90 \times 70-80$ \\
Cyclotrichium sp. & $20 \times 10$ \\
Gen. sp. (unknown) & $25 \times 15$ \\
Total number of species & 17 \\
\hline
\end{tabular}

depth of $5 \mathrm{~m}$ in Stn 11. In waters deeper than $25 \mathrm{~m}$, the abundance of $L$. strobila was less than 50 ind. $\mathrm{l}^{-1}$ (Fig. 2). The abundance (138 ind. $\mathrm{l}^{-1}$ ) of L. strobila was found to be lower in the surface waters in Stn 14, while it was high in the subsurface waters (432 and 312 ind. $\mathrm{l}^{-1}$ at 5 and $15 \mathrm{~m}$ depths, respectively). In the case of Strombidium compressum (Fig. 5), there were peaks in the surface and subsurface waters with the exception of Stn 16, where there was no surface abundance peak.

The abundance of other aloricate ciliates was lower than 80 ind. $^{-1}$. Tintinnids occurred occasionally. The maximum tintinnid abundance was 100 ind. $\mathrm{l}^{-1}$ in the surface waters of Stns 3 and 4. At other stations and depths, tintinnid abundance appeared to be lower than 20 ind. $\mathrm{l}^{-1}$. The total ciliate abundance fell in the range of 40 to 3420 ind. $\mathrm{l}^{-1}$.

Ciliate biomass in surface water and the water column ranged from 0.15 to $6.76 \mu \mathrm{g} \mathrm{C}^{-1}$ and 0.4 to $134.4 \mathrm{mg} \mathrm{C} \mathrm{m}^{-2}$, respectively (Fig. 4). Although the abundance of Strombidium compressum was much higher than that of Laboea strobila, the biomass of $L$. strobila was dominant both at the surface and in the column.

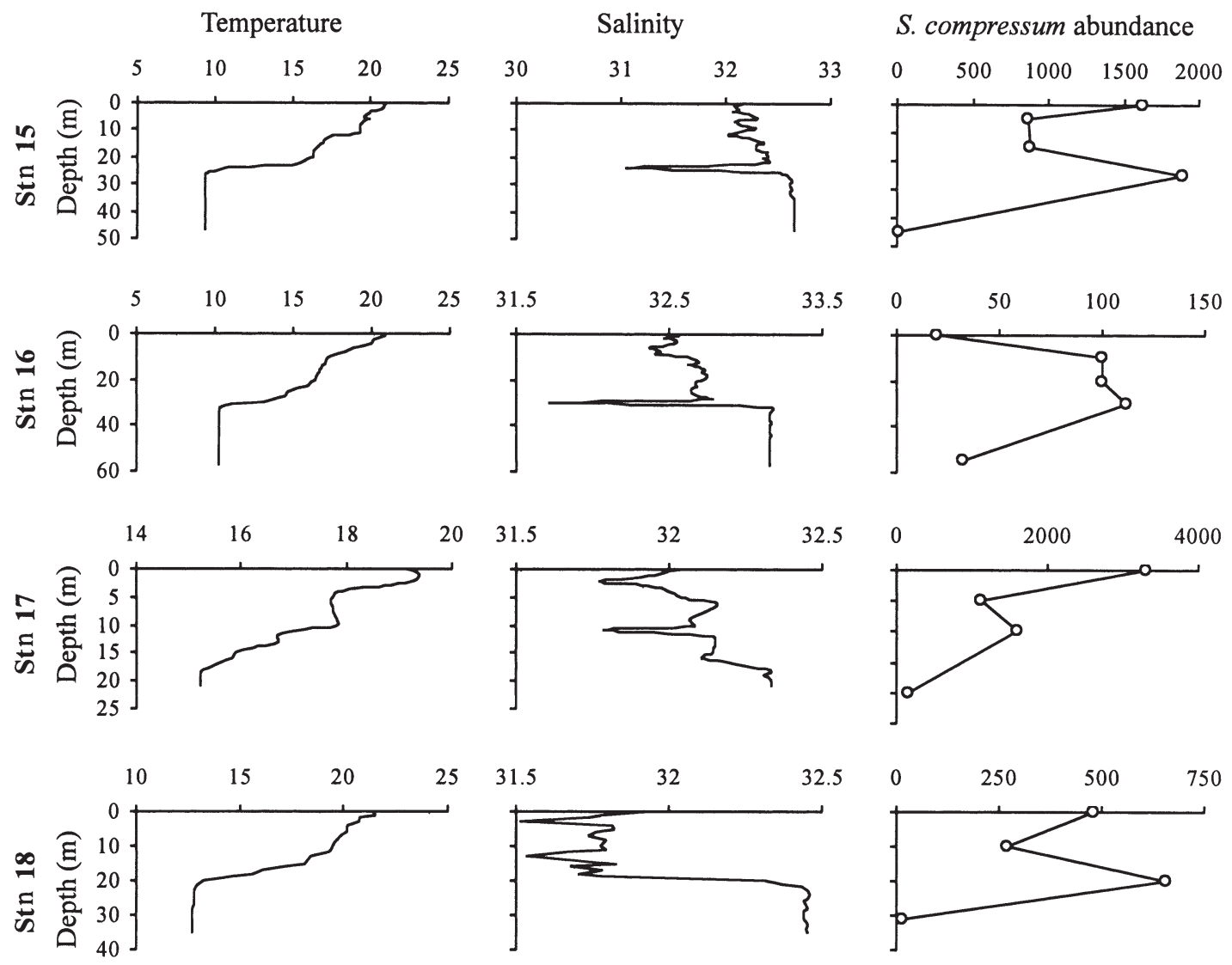

Fig. 5. Vertical profiles of temperature $\left({ }^{\circ} \mathrm{C}\right)$, salinity and Strombidium compressum abundance (ind. ${ }^{-1}$ ) at Stns $15,16,17$ and 18 


\section{Copepod egg and nauplii distribution}

The distributions of copepod eggs and nauplii are shown in Fig. 6. Eggs and nauplii in surface water were considered to be the food immediately available to the fish larvae, while those at depth were the potential food with vertical migration. In the surface waters, the abundance of copepod eggs ranged between 0.3 and 3.1 ind. $\mathrm{l}^{-1}$ with more than 2.0 ind. $\mathrm{l}^{-1}$ at Stns 1,4 , 15 and 17 . The average abundance among the upper 4 depths fell in the range of 0.2 to 2.8 ind. $\mathrm{l}^{-1}$; Stns 4,5 and 17 had values more than 2.5 ind. $\mathrm{l}^{-1}$.

The copepod nauplii abundance in the surface waters fell in the range of 1.0 to 29.4 ind. $\mathrm{l}^{-1}$ with more than 10 ind. $\mathrm{l}^{-1}$ at Stns 10, 15 and 18. The average abundance among the upper 4 depths was 1.1 to 15.6 ind. $^{-1}$; Stns 6,15 and 18 had abundances more than 10 ind. $\mathrm{l}^{-1}$.

\section{Microzooplankton grazing pressure}

The results of the 6 dilution incubations are shown in Fig. 7 and Table 1. Phytoplankton grew at rates 0.2 to $0.74 \mathrm{~d}^{-1}$. Microzooplankton grazed at rates 0 to $0.61 \mathrm{~d}^{-1}$. Two of the experiments showed no microzooplankton grazing. For the experiments with positive microzooplankton grazing, $P_{\mathrm{i}}$ and $P_{\mathrm{p}}$ were 17 to $46 \%$ and 35 to $109 \% \mathrm{~d}^{-1}$, respectively.

\section{DISCUSSION}

\section{Ciliates}

The final concentration of acid Lugol's solution for the fixation of the ciliates was only $1 \%$ in this study. This concentration is at the lower end of those (0.6 to $20 \%$ ) in the references (Harris et al. 2000). High concentrations $(10 \%$ in Throndsen 1978,10 to $20 \%$ in Stoecker et al. 1994) of acid Lugol's solution caused the lowest losses in the ciliate counts. Therefore, the ciliate concentrations in this study may have been underestimated.

The ciliate communities can be divided into 3 parts, as shown in Fig. 3. Part A was a cool area occupied by tintinnids. Part B was an area with high temperature where Laboea strobila peaked. Strombidium compressum was common in Part C. The characteristic vertical profile of $L$. strobila abundance, if not light related as it is a mixotrophic species (Stoecker et al. 1987), might be attributed to an inclination for warm water. Unlike L. strobila, $S$. compressum seemed to prefer the thermocline (Fig. 2). Many authors have discussed the occurrence of ciliates and hydrographic conditions
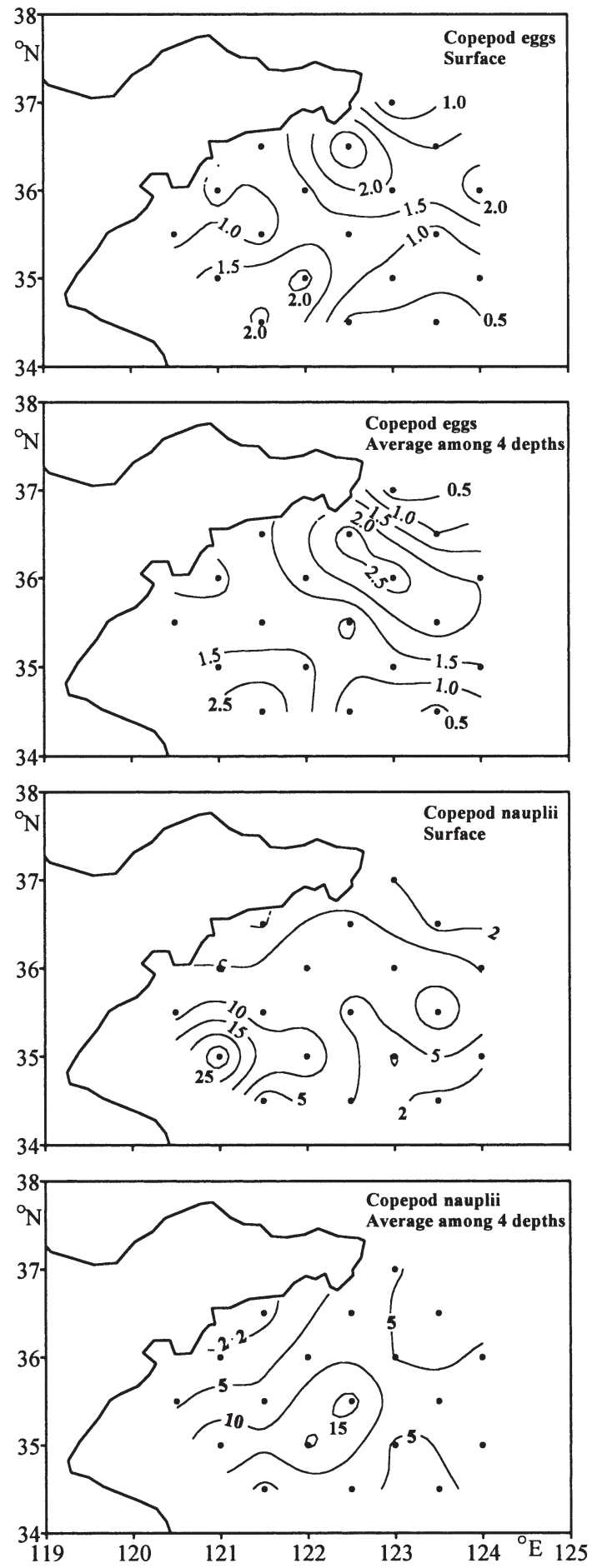

Fig. 6. Abundance (ind. $\mathrm{l}^{-1}$ ) of copepod eggs and nauplii in the surface waters and the average among 4 depths (surface, 5, 10 and $20 \mathrm{~m}$ )

(Sanders 1987, Kamiyama \& Tsujino 1996, Cordeiro et al. 1997). Sanders (1987) suggested that microzooplankton abundance and distribution are determined in part by physical factors including temperature, 


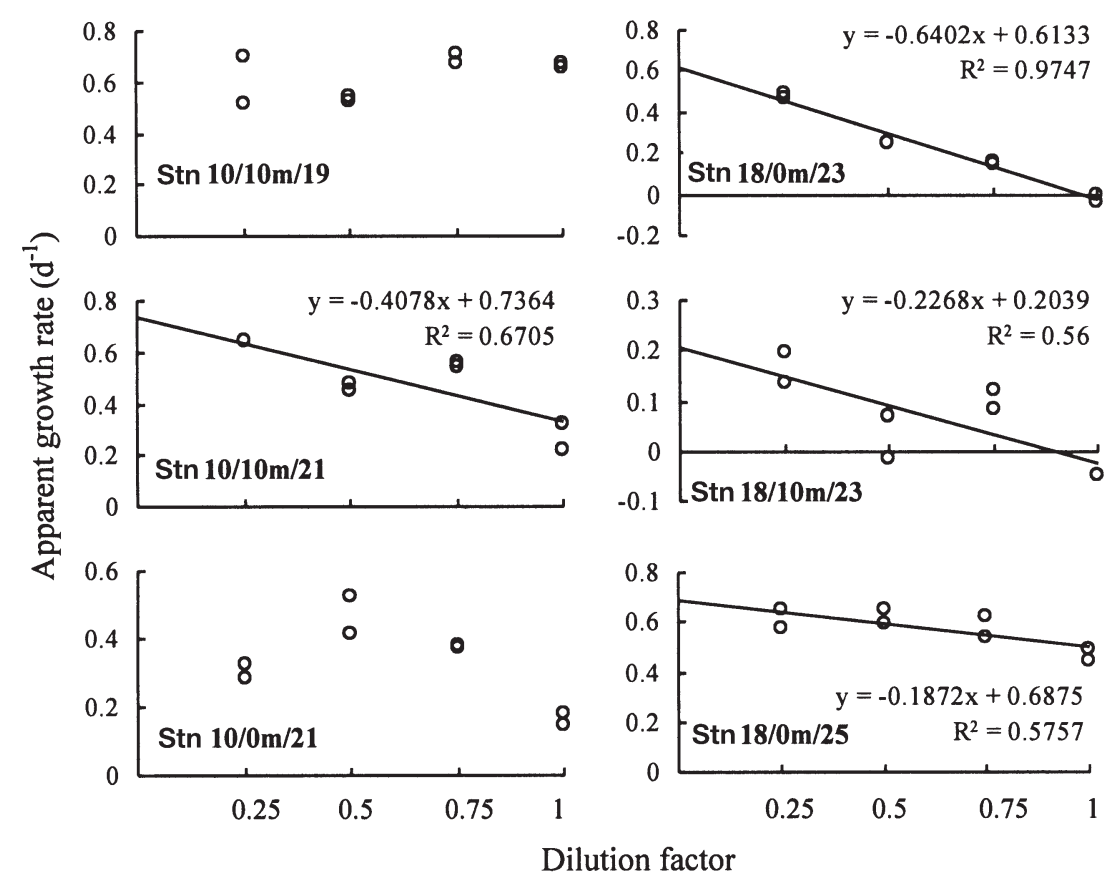

Fig. 7. Regressions between the dilution factors and the apparent growth rates of the dilution experiments

salinity and currents. Kamiyama \& Tsujino (1996) noted that the occurrence of most tintinnids was strongly related to temperature, water column stability and abundance of nanophytoplankton, but the particular response to these environmental factors was species specific. In the study of Cordeiro et al. (1997), the distribution patterns of tintinnid species showed a certain relationship with the circulation of waters in the North Sea. In this study, water circulation influenced the distribution of ciliates. It seems that the different ciliate species prefer different environmental factors (especially temperature).

\section{Relationship between copepod nauplii and anchovy larvae}

Feeding habits of larval anchovy have been extensively studied by examining gut contents (Park \& Cha 1995, Hirakawa \& Ogawa 1996, Hirakawa et al. 1997 and references therein). As in this study, copepod eggs and nauplii were the dominant food items while no aloricate ciliate was found in the guts of anchovy larvae in the past studies.

We found that the patch of anchovy larvae did not coincide with that of copepod nauplii and eggs. Anchovy post-larvae were abundant at Stn 17, where the copepod nauplii abundance was low while copepod egg abundance was high. If copepod eggs and nauplii were considered together as the food particles of anchovy larvae, the peak of anchovy larvae abundance was not coincident with that of copepod eggs and nauplii. Similar results were also found in other studies. In Hiroshima Bay, Uye \& Yamaoka (1990) found that the spawning ground of the anchovy Engraulis japonica was the open bay area while the high densities of copepod nauplii were in the innermost part of the bay. Results of Matsushita et al. (1988) showed that patches of larvae rarely coincided with those of food organisms (copepod nauplii).

Additionally, the abundances of copepod nauplii and eggs were much lower than the threshold food density for survival estimated by rearing experiments. On the basis of laboratory experiment, O'Connell \& Raymond (1970) reported that northern anchovy larvae required a minimum concentration of 1000 copepod nauplii $\mathrm{l}^{-1}$. In the study of Laurence (1974), 500 to 3000 copepod nauplii were required for the haddock Melanogrammus aeglefinus to survive. Bay anchovy Anchoa mitchilli Valenciennes larvae required 1500 to 2000 copepod nauplii $\mathrm{l}^{-1}$ to achieve significant survival (Saksena \& Houde 1972). The abundance of copepod nauplii in the sea is usually lower than this level (Houde 1978).

\section{Relationship between ciliates and anchovy larvae}

Because the abundance of copepod nauplii is usually below threshold concentrations, several authors have suggested that larvae exploit other prey. Lasker et al. (1970) reported that the dinoflagellate Gymnodinium splendens might have an important role for survival of first-feeding larvae of the northern anchovy Engraulis mordax. Uye \& Yamaoka (1990) hypothesized that E. japonicus larvae might depend on small scale nauplii patchness, which was not detected in their study (62 to $309 \mathrm{~m}$ interval) or on phytoplankton as a supplementary food under scarce nauplii supply. The first-feeding cod larvae seem to have high trophic flexibility by incorporation of algae (as small as $10 \mu \mathrm{m}$ ) and ciliates in their diet. At low copepod density, cod larvae may achieve maintenance ration if they feed on both algae and ciliates (Van der Meeren \& Nass 1993). The study of Nagano et al. (2000) showed that both tintinnid and naked ciliates play important roles as alternative food 
sources to copepod nauplii by enhancing the survival of fish larvae. Therefore, the ciliates in Stn 17 may have been prey for first-feeding anchovy larvae, preventing initial starvation and prolonging the time to irreversible starvation of fish larvae.

The ciliates in this study were appropriate prey of anchovy larvae in terms of size. The mouth size of the first-feeding anchovy larvae was in the range of 230 to $280 \mu \mathrm{m}$ (Shirota 1970). According to Hunter \& Kimbrell (1980), if the mean diameter of prey eaten by anchovy larvae were about $40 \%$ of their mouth width, the anchovy larvae could eat food particles smaller than $80 \mu \mathrm{m}$. Laboratory experiments have shown that fish larvae of some species ingest quite small particles such as phytoplankton $<10 \mu \mathrm{m}$ diameter (Van der Meeren 1991). The dimensions of the ciliate species listed in Table 2 fell in the above range.

\section{The dilution incubations}

In the design of the dilution incubation method, nutrients should be added to the dilution bottles to prevent them from becoming depleted in the less dilute treatment (Landry \& Hassett 1982), especially when nutrient concentrations are low as in this study. The estimated $k$ will be overestimated when no nutrient is added to the dilution series. However, no trace of overestimation of phytoplankton growth rate showed up in Fig. 7. On the other hand, results of dilution incubations with nutrient addition cannot be considered to be in situ growth rate of phytoplankton. McManus \& Ederington-Cantrell (1992) reported 2 parallel dilution series with and without nutrient addition. The phytoplankton growth rate of the series with nutrient addition was 4 -fold higher than that of the series without nutrient addition, while the 2 grazing rates were similar.

Dilution experiments have been carried out in many sites around the world (Dolan et al. 2000). The results of this study ( $k$ : 0.14 to $0.74 ; g$ : 0 to 0.61 ) were within the wide ranges of the previous data ( $k: 0$ to $2.14 ; g: 0$ to 2.11; Zhang \& Wang 2000 and references therein), but at the lower end. There are 2 possible explanations for the low phytoplankton growth rate and microzooplankton grazing rate. Firstly, the studied area was obviously oligotrophic. Low nutrient (Table 1) concentration limited the phytoplankton growth. Secondly, there may be toxic effects of Niskin sampling bottles. The Niskin water bottles used in this study had internal rubber closure spring and O-rings, which are toxic to a number of protists (Price et al. 1986, Harris et al. 2000).

In this study, 3 parallel experiments were carried out at every station. The growth rates in the same depths of each station were roughly equal (10 m at Stn 10 and $0 \mathrm{~m}$ at Stn 18). However, microzooplankton grazing rates showed large variations $(0.41$ and 0 at Stn 10 , 0.61 and 0.19 at Stn 18). The differences suggested that the results of the dilution experiments could only be considered as an instantaneous indication.

\section{Conclusion}

We examined the spatial distribution of ciliates, copepod nauplii and eggs, Engraulis japonicus post-larvae and microzooplankton herbivorous activity. As a food item of the E. japonicus post-larvae, the abundance of copepod nauplii and eggs was low. The peaks of ciliate and E. japonicus post-larvae abundance coincided. Although not found in the gut of E. japonicus post-larvae, aloricate ciliates might help the first-feeding anchovy larvae to prevent initial starvation and prolong the time to irreversible starvation. The dilution experiments showed that both the phytoplankton growth rate and microzooplankton grazing rate were comparatively low.

Acknowledgements. This study was supported by special funds from National Key Basic Research Program of PR China G19990437. We thank the crew of RV 'Beidou' for their help. Two anonymous referees offered valuable advice on an earlier draft of this manuscript.

\section{LITERATURE CITED}

Beers JR, Reid MS, Stewart GL (1980) Microplankton population structure in Southern California nearshore waters. Mar Biol 60:209-226

Burkill PH, Head E, Fransz G, Lenz M, Landry M (1990) Grazing by microzooplankton. In: Core measurement protocols: reports of the Core Measurement Working Groups. JGOFS Rep 6:31-37

Carey PG (ed) (1992) Marine interstitial ciliates. Chapman \& Hall, London

Cordeiro TA, Brandini FP, Martens P (1997) Spatial distribution of the Tintinnina (Ciliophora, Protista) in the North Sea, spring of 1986. J Plankton Res 19:1371-1383

Dolan JR, Gallegos CL, Moigis A (2000) Dilution effects on microzooplankton in dilution grazing experiments. Mar Ecol Prog Ser 200:127-139

Gifford DJ (1991) The protozoan-metazoan trophic link in pelagic ecosystems. J Protozool 38:81-86

Gilron GL, Lynn DH (1989) Assuming a 50\% cell occupancy of the lorica overestimates tintinnine ciliate biomass. Mar Biol 103:413-416

Govoni JJ, Chester AJ (1990) Diet composition of larval Leiostomus xanthurus in and about the Mississippi River plume. J Plankton Res 12:819-830

Harris R, Wiebe P, Lenz J, Skjoldal HR, Huntley M (eds) (2000) ICES zooplankton methodology manual. Academic Press, London

Hirakawa K, Ogawa Y (1996) Characteristics of the copepod assemblage in the southwestern Japan Sea and its impli- 
cations for anchovy population dynamics. Bull Jpn Sea Natl Fish Res Inst 46:45-64

Hirakawa K, Goto T, Hirai M (1997) Diet composition and prey size of larval anchovy Engraulis japonicus, in Toyama Bay, southern Japan Sea. Bull Jpn Sea Natl Fish Res Inst 47:67-78

Hjort J (1914) Fluctuations in the great fisheries of northern Europe reviewed in the light of biological research. Rapp P-V Reun Cons Perm Int Explor Mer 20:1-228

Houde ED (1978) Critical food concentrations for larvae of three species of subtropical marine fishes. Bull Mar Sci 28: 395-411

Hunter JR, Kimbrell CA (1980) Early life history of Pacific mackerel, Scomber japonicus. Fish Bull US 78:89-101

Jenkins GP (1987) Comparative diets, prey selection, and predatory impact of co-occuring larvae of two flounder species. J Exp Mar Biol Ecol 110:147-170

Kamiyama T, Tsujino M (1996) Seasonal variation in the species composition of tintinnid ciliates in Hiroshima Bay, the Seto Inland Sea of Japan. J Plankton Res 18:2313-2327

Kofoid CA, Campbell AS (1929) A conspectus of the marine and fresh-water ciliata belonging to the suborder Tintinnoinea, with descriptions of new species principally from the Agassiz expedition to the eastern tropical Pacific 1904-1905. Univ Calif Publ Zool 34:1-403

Landry MR, Hassett RP (1982) Estimating the grazing impact of marine microzooplankton. Mar Biol 67:282-288

Lasker R, Feder HM, Theilacker GH, May RC (1970) Feeding, growth and survival of Engraulis mordax larvae reared in the laboratory. Mar Biol 5:345-353

Lessard EJ, Martin MP, Montagnes DJS (1996) A new method for live-staining protists with DAPI and its application as a tracer of ingestion by walleye pollock (Theragra chalcogramma (Pallas)) larvae. J Exp Mar Biol Ecol 204:43-57

Laurence GC (1974) Growth and survival of haddock (Melanogrammus aeglefinus) larvae in relation to planktonic prey concentration. J Fish Res Board Can 31: 1415-1419

Longhurst AP, Fransz G, Landry M, Burkill P, Lenz J (1990) Microzooplankton. In: Core measurement protocols: Reports of the Core Measurement Working Groups. JGOFS Rep 6:25

Lynn DH (1992) Protargol staining. In: Lee JJ, Soldo AT (eds) Protocols in protozoology. Soc Protozool C-4.1.

Lynn DH, Montagnes DJS, Small EB (1988) Taxonomic descriptions of some conspicuous species in the family Strombidiidae (Ciliophora, Oligotrichida) from the Isles of Shoals, Gulf of Maine. J Mar Biol Assoc UK 68:259-276

Lynn DH, Montagnes DJS, Dale T, Gilron GL, Strom SL (1991) A reassessment of the genus Strombidinopsis (Ciliophora, Choreotrichida) with descriptions of four new planktonic species and remarks on its taxonomy and phylogeny. J Mar Biol Assoc UK 71:597-612

Maeda M, Carey PG (1985) An illustrated guide to the species of the family Strombidiidae (Oligotrichida, Ciliophora), free swimming protozoa common in the aquatic environment. Bull Ocean Res Inst Univ Tokyo 19:1-68

Matsushita K, Shimizu M, Nose Y (1988) Food density and rate of feeding larvae of anchovy and sardine in patchy distributions. Bull Jpn Soc Sci Fish 54:401-411

May RC (1974) Larval mortality in marine fishes and the critical period concept. In: Blaxter JHS (ed) The early life history of fish. Springer-Verlag, Berlin, p 3-19

McManus GB, Ederington-Cantrell MC (1992) Phytoplankton pigments and growth rates, and microzooplankton grazing in a large temperate estuary. Mar Ecol Prog Ser 87: $77-85$
Montagnes DJS, Lynn DH (1991) Taxonomy of chereotrichs, the major marine planktonic ciliates, with emphasis on the aloricate forms. Mar Microb Food Webs 5:59-74

Nagano N, Iwatsuki Y, Kamiyama T, Nakata H (2000) Effects of marine ciliates on survivability of the first-feeding larval surgeonfish, Paracanthurus hepatus: laboratory rearing experiments. Hydrobiologia 432:149-157

O'Connell CP, Raymond LP (1970) The effect of food density on survival and growth of early post yolk-sac larvae of the northern anchovy (Engraulis mordax Girard) in the laboratory. J Exp Mar Biol Ecol 5:187-197

Ohman MD, Theilacker GH, Kaupp SE (1991) Immunochemical detection of predation on ciliate protists by larvae of the northern anchovy (Engraulis mordax). Biol Bull 181: 500-504

Park KJ, Cha SS (1995) Food organisms of postlarvae of Japanese anchovy (Engraulis japonica) in Kwangyang Bay. J Korean Fish Soc 28:247-252

Pierce RW, Turner JT (1992) Ecology of planktonic ciliates in marine food webs. Rev Aquat Sci 6:139-181

Price NM, Harrison PH, Landry MR, Azam F, Hall KJF (1986) Toxic effects of latex and Tygon tubing on marine phytoplankton, zooplankton and bacteria. Mar Ecol Prog Ser 34: 41-49

Putt M, Stoecker DK (1989) An experimentally determined carbon:volume ratio for marine 'oligotrichous' ciliates from estuarine and coastal waters. Limnol Oceanogr 34: 1097-1103

Saksena VP, Houde ED (1972) Effect of food level on the growth and survival of laboratory-reared larvae of bay anchovy (Anchoa mitchilli Valenciennes) and scaled sardine (Harengula pensacolae Goode and Bean). J Exp Mar Biol Ecol 8:249-258

Sanders RW (1987) Tintinnids and other microzooplanktonseasonal distributions and relationships to resources and hydrography in a Maine estuary. J Plankton Res 9:65-77

Shirota A (1970) Studies on the mouth size of fish larvae. Bull Jpn Soc Sci Fish 36:353-368

Small EB, Lynn DH (1985) Phylum Ciliophora Doflein, 1901. In: Lee JJ, Hutner SH, Bovee EC (eds) An illustrated guide to the Protozoa. Society of Protozoologists, Allen Press, Lawrence, KS, p 393-575

Stoecker DK, Capuzzo JM (1990) Predation on protozoa: its importance to zooplankton. J Plankton Res 12:891-908

Stoecker Dk, Michaels AE, Davis LH (1987) Large proportion of marine planktonic ciliates found to contain functional chloroplasts. Nature 326:790-792

Stoecker DK, Gifford DJ, Putt M (1994) Preservation of marine planktonic ciliates: losses and cell shrinkage during fixation. Mar Ecol Prog Ser 110:293-299

Strickland JDH, Parsons TR (1972) A practical handbook of seawater analysis. J Fish Res Board Can 167:1-310

Tang Q (2000) The new age of China-GLOBEC. GLOBEC Int Newsl 6.1:13

Throndsen J (1978) Preservation and storage. In: Sournia A (ed) Phytoplankton manual. UNESCO, Paris, p 69-74

Uye S, Yamaoka T (1990) Vertical and horizontal distribution of copepod nauplii as food for anchovy (Engraulis japonica) in Hiroshima Bay. Bull Jpn Soc Fish Oceanogr 54: 341-351

Uye S, Nagano N, Tamaki H (1996) Geographical and seasonal variations in abundance, biomass and estimated production rates of microzooplankton in the Inland Sea of Japan. J Oceanogr 52:689-703

Van der Meeren T (1991) Algae as first food for cod larvae, Gadus morhua L.: filter feeding or ingestion by accident? J Fish Biol 39:225-237 
Van der Meeren T, Nass T (1993) How does cod (Gadus morhua) cope with variability in feeding conditions during early larval stages? Mar Biol 116:637-647

Verity PG, Stoecker DK, Sieracki ME, Nelson JR (1993) Grazing, growth and mortality of microzooplankton during the 1989 North Atlantic spring bloom at $47^{\circ} \mathrm{N}, 18^{\circ} \mathrm{W}$. DeepSea Res 40:1793-1814

Wilbert N (1975) Eine verbesserte Technik der Protargolimprägnation für Ciliaten. Mikrokosmos 64:171-179

Zhang J, Yu G, Liu S, Xu H, Liu M (1997) Nutrient

Editorial responsibility: John Dolan,

Villefranche-sur-Mer, France element dynamics of three North China estuaries: the Luanhe, Shuangtaizihe and Yalujiang. Estuaries 20: $110-123$

Zhang W, Wang R (2000) Summertime ciliate and copepod nauplii distributions and microzooplankton herbivorous activity in the Laizhou Bay, Bohai Sea, China. Estuar Coast Shelf Sci 51:103-114

Zhu D, Iversen SA (1990) Anchovy and other fish resources in the Yellow Sea and East China Sea November 1984-April 1988. Mar Fish Res 11:1-51

Submitted: March 2, 2001; Accepted: October 8, 2001

Proofs received from author(s): March 22, 2002 